\title{
The First Decision Rendered by the Supreme Court of Iowa
}

\author{
An Article by Henry K. Peterson \\ Justice Supreme Court of Iowa
}

It is of interest, not only to lawyers, but also to all citizens of Iowa who are interested in historical events, to read a brief article concerning the first case appealed to the supreme court of Iowa.

The case is entitled "In the Matter of Ralph (A Colored Man), on Habeas Corpus," and appears in Iowa Reports, Morris, Vol. I, page 1.

It is apparent from the title that same pertains to a slave. The question of slavery having been settled by the Civil war, the decision is not of value as a legal precedent, but only as a matter of historical interest.

The case was submitted and decided in July term 1839, when Iowa was still a territory. Iowa had been separated from Wisconsin territory and became a distinct territory under Act of Congress enacted June 12, 1838. The Territorial Act provided for a supreme court of three justices to be appointed by the president. The first chief justice was Charles Mason and the two associate justices were Joseph Williams and Thomas A. Wilson. The opinion in this case was written by Chief Justice Mason.

In Missouri, Ralph was the slave of a man by the name of Montgomery. In 1834 Ralph entered into a written agreement with Montgomery under which he was to come to Dubuque, which was then in the territory of Wisconsin. Under this agreement he stipulated to pay Montgomery for his freedom the sum of $\$ 450.00$; with interest from January 1, 1835. Ralph worked in the lead mines at Dubuque through the years, but failed to pay the money to Montgomery. In 1839, Montgomery came to Dubuque and with the help 
of a justice of the peace took possession of Ralph. Habeas corpus proceeding was immediately started in the district court, but since the supreme court judges were also the district judges in various sections of the territory, it was stipulated by all parties concerned that the case should be immediately certified to the supreme court for decision.

The Ordinance of 1787 which established the laws for what was known as Northwest territory, and which pertained to Wisconsin territory to which Ralph first came, had two provisions prohibiting slavery in any part of the territory. The second article stated: "No man shall be deprived of his liberty, or property, but by the judgment of his peers, or the law of the land." The sixth article provided: "There shall be neither slavery nor involuntary servitude in the said territory, otherwise than in the punishment of crimes whereof the parties shall have been duly convicted."

The territory of Iowa was a part of the Louisiana Purchase. Under the Missouri Compromise Act of 1820, Missouri came into the union as a slave state, but the following provision became a part of the Act: "In all that territory ceded by France to the United States, under the name of Louisiana, which lies north of thirty-six degrees and thirty minutes north latitude, not included within the limits of the state contemplated by this act, slavery and involuntary servitude, otherwise than in the punishment of crimes, whereof the parties shall have been duly convicted, shall be, and is hereby, forever prohibited."

The principal contention of Montgomery was that Ralph was a fugitive from justice and that under Section 2, Article IV of the Constitution of the United States with reference to fugitive slaves, in effect at that time, he was entitled to the return of his property. He also claimed that while the general provision concerning no slavery pertained to Iowa territory under the Missouri Compromise Act of 1820, yet it was necessary that specific legislation to implement 
the Act be, adopted by Congress as to each territorial division.

With prophetic foresight, many years before the Civil war, Judge Mason said: ". . . it [the case] involves an important question, which may ere long, if unsettled, become an exciting one. ..." The court held the Ordinance of 1787 was effective as to Wisconsin territory when Ralph came to Dubuque, and the Missouri Compromise Act of 1820 was effective as to Iowa territory in which he found himself at the time of the action. $\mathrm{He}$, therefore, held he was a free man and the writ of habeas corpus was sustained. As an expression of the reasoning of the court in connection with the matter, we quote the following brief excerpts from the opinion:

"From the facts agreed upon in this case, it seems that the claimant permitted his slave to come to this territory. The permission seems to have been absolute; but there was also an understanding that the latter was to pay the former a certain amount, as the price of his freedom. How the failure to comply with this understanding could render a removal, undertaken with the master's consent, an escape, we are unable to comprehend. . . . It is a debt which he ought to pay, but for the non-payment of which no man in this territory can be reduced to slavery. . . . The master who, subsequently to that Act permits his slave to become a resident here, cannot afterward exercise any acts of ownership over him within this territory. . . Property, in the slave, cannot exist without the existence of slavery; the prohibition of the latter annihilates the former, and, this being destroyed, he becomes free. ... When, in seeking to accomplish his object, he [Montgomery] illegally restrains a human being of his liberty, it is proper that the laws, which should extend equal protection to men of all colors and conditions, should exert their remedial interposition."

I direct the attention of the reader to the fact that this case occurred, and this opinion was written, twenty- 
two years before the Civil war. Yet Judge Mason, with keen insight, and unusual prophetic vision, anticipated and pronounced some of the great principles which were only settled a quarter of a century later by a national and tragic war.

The Story of Winthrop, Iowa, 1857-1957. By Diane Gail Dey. Winthrop News Press. 118 pages.

Fortunate is the community that has a resident who rates as a historian; and doubly blessed is one persistent and capable in research and with a knowledge of what is essential in framing a narrative replete with factual data covering an entire century of local history.

Advantageous also, was inspiration of the author drawn from the writing of a thesis originally in partial fulfillment of the Bachelor of Arts degree in the department of Sociology of Cornell college, Mount Vernon, Iowa.

An informative and illustrated volume, with adequate table of contests, detailing the record of Winthrop, Iowa, official and personal, well documented, covering a century's history of an enterprising town and its people, has been most capably produced and published by Miss Dey.

In addition to the record of early settlement, establishment of the settlement and organization of the town, fortunately there is included a complete listing of mayors, postmasters, pastors and priests of local churches, railroad station agents, school superintendents, with dates of terms of service, together with Civil war veterans buried there and those from the community serving in World wars I and II. -

The growth of the local schools, the social groups, organizations and recreations all are similarly treated, with the usual centennial summary and review, all most intelligently presented. The volume is a valuable addition to the history of Buchanan county and well worth a place in any library. 
Copyright of Annals of Iowa is the property of State of Iowa, by \& through the State Historical Society of Iowa and its content may not be copied or emailed to multiple sites or posted to a listserv without the copyright holder's express written permission. However, users may print, download, or email articles for individual use. 